\title{
Study of Conflict between Adizes's Leadership Styles and Glasser's Five Basic Needs
}

\author{
Hassankhani Shiva \\ M.A. in General Psychology, Department of Psychology, Faculty of Humanities, Neyshabur Branch, \\ Islamic Azad University, Neyshabur, Iran
}

\section{Toozandehjani Hassan*}

Assistant Professor, Ph. D. of Psychology, Department of Psychology, Faculty of Humanities, Neyshabur Branch, Islamic Azad University, Neyshabur, Iran *Corresponding Author Email: H. Toozandehjani@ymail.com

\author{
Doi:10.5901/mjss.2016.v7n3s3p89
}

\begin{abstract}
This study aims to examine the relationship between leadership styles with the intensity of the basic needs of managers and has been done by focusing on their personality type. The research method is descriptive and correlational. The population includes all Industrial and producer managers in the city of Mashhad. The sample for this study includes 36 senior managers of an Industrial and manufacturing group. To collect data, the Myers-Briggs Type Indicator (MBTI) and questionnaires of Glaser's five basic needs were used. Data analysis has been performed using Pearson's correlation coefficient and regression analysis. The correlation test results show that the administrative leadership style $(A)$ and entrepreneur $(E)$ on the needs of survival and freedom are significantly different $(p<0.0001)$. Managers with administrative leadership style have a higher survival need and lower freedom need rather than managers with entrepreneurial leadership style. Since both of them cover both mental and psychological needs proposed in Glaser theory, so we can conclude that the proposed conflict between $A$ and $E$ styles in Adizes's theory is due to the difference in the intensity of their basic needs.
\end{abstract}

Keywords: leadership styles, basic needs, personality types

\section{Introduction}

Conducted according to the research, an increasing cognitive approach in Industrial and Organizational Psychology especially the application of cognitive techniques in the field of management and business is observed (Armstrong, Cools and Smith, 2012). The cognitive approach distinguishes among people. How they think, interpret, learn, decide and communicate with others (Watkins, 1977). The people benefit of innovative approaches for in the complex processes that form the foundation of their behavior (Messiek, 1976). The origin and rise of the cognitive approach return to Galton (1883), Jung (1923) and Allport (1973) researches. The first systematic study of cognitive was done in 1940, when Watkins et al. (1940), developed the theory of Field Dependence/Independence (FDI) based on a continuum of modes of perception. Since then, Jung's theory (especially its practical approach) is widely used as Myers-Briggs index (MBTI) (Myers, 1962), as an indicator of cognitive approach in both theoretical and practical organization. (Hough and Ogilvie, 2005; Gardner and Martinko, 1996). Researchers did special studies on professional groups (accountants) and professional levels (managers) and concluded that the approach of accountants is more inclined to adaption rather than creativity and innovation (Gul, 1986), and are more analytical rather than intuitive (Hicks et al., 2007) and their character is more intuitive, thinking and judgmental (ISTJ and ESTJ) (Parkinson's and Hicks, 2007). In another study it was concluded that the variety of intuitive (N) in MBTI index is observed more among senior managers, while all sense types (S) are normally common among middle/ lower levels (Gardner and Martinko, 1996; Schloemer and Schloemer, 1997). A study was done on the issue of the appropriateness of jobs and employed and effectiveness of recruitment methods (Riding and Rayner, 1998) and conducted and concluded that the sense types in more efficient structured and daily routine activities are of witnesses types. In the characteristics of a successful manager and effective of factors mismanagement, Adizes concluded that managers and leaders are divided into four categories: the Producer $(P)$, Administrator (A), Entrepreneur (E) and the Integrator (I) and it was called PAEI pattern (1).

Producer ( $P$ style): The main feature of these managers is their responsibility. If they see a problem, it makes them unrest. The problem that they see is their own problem. They are diligent and faithful and they act reactive. And they feel 
a sense of satisfaction when they finish their jobs. In undeveloped conditions in which there is a lot of work to do, these are the best managers.

Administrator (A style): These managers give the affairs a kind of discipline. Laws and regulations are very important to them. They came on time and, regardless of what they do, they leave on time. Organization or company is bankrupt, but just at the time of a great control they do a pointless work. For them, it is more important how to do rather than why. They feel satisfied of being regulated on their work. Doing jobs properly is very important for them. Under normal conditions, the managers prevent of confusion, disorder and personal opinions. Because the disorder costs are greater than the cost of the rule, in the absence of the directors, company or organization costs increases.

Entrepreneur (E type): they are very self-confident. See things that others do not. They are forethoughtful and ahead of ordinary people. They love their opinions and that is why they are entrepreneurs. They have economic development thoughts. Artists, inventors and explorers are of this type. They are macro perspective and they have two features of having information and risk appetite. Usually they do under not employed and they are of the most expensive managers. They are thoughtful and the number of them are very low.

Integrator (I style): the managers brought together different people with different and contrasting tastes. They are warm and unifying. They generate solidarity and synergies.

Conceptually, the Adizes Methodology is a contingency theory of human organizations. Contingency or congruency theories in organizational studies emphasize that there is no single best type of organization. Instead, these theories emphasize the importance of fit (Aldrich, 1979). Fitness can be described as the 'aligning' or 'matching' of organizational resources to environmental opportunities and threats (Chandler, 1962). The Adizes Methodology can be described as a contingency theoretical approach to organizational management that analyses all the components of fitness using a competing values (or concern structure) framework (LaChapelle, 2008). The first study of the relationship between management styles and Briggs PAEI Myers index (MBTI) was conducted by Nordovik and Brovold (1998), in Norwegian managers. The results of this study showed significant differences in career preferences and personality of managers in four Producer, Entrepreneur, Administrator and Integrator styles. Kirsey (1984), according to MBTI theory and ideas of the philosophers of ancient Greece, divided the temperaments of people to four categories: Idealist (NF group): intuition and feelings; Rational (NT group): intuition and thinking; Guardian (SJ Group): sensing and judging; Artisan (SP group): sensing and perceiving.

Recker (1991), also proposed that the leadership style of Intuition-Thinking (NT) profiles is Entrepreneurial (E). And also, the leadership style of Intuition-Feeling (NF) profiles is Integrator (I), the leadership style of Sensing-Judging (SJ) profiles is Administrator (A) and the leadership style of Sensing-Perceiving (SP) profiles is Producer (P).

Table 1. Relationship between personality type - temperaments - leadership style

\begin{tabular}{cccccc}
\hline \multicolumn{3}{c}{ MBTI Personality types } & & Kirsey Temperaments & Adizes Leadership Styles \\
\hline ESTP & ISTP & ESFP & ISFP & SP & P \\
\hline ESFJ & ISFJ & ESTJ & ISTJ & SJ & A \\
\hline ENTJ & INTJ & ENTP & INTP & NT & E \\
\hline ENFJ & INFJ & ENFP & INFP & NF & I
\end{tabular}

Adizes (1979), commented his opinion on leadership styles in a $2 \times 2$ matrix as stating that an Integrator style conflict with Producer style and Entrepreneur style conflicts with Administrator style.

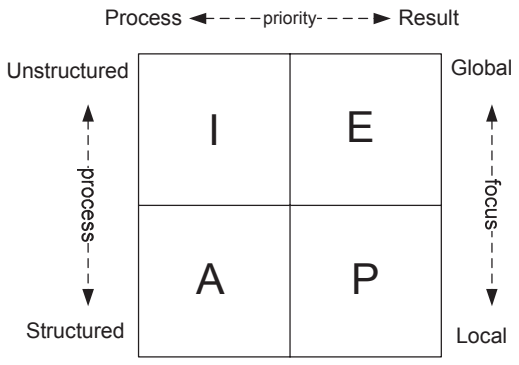

Figure 1. Matrix of differences in Adizes four leadership styles (Adizes, 1979). 
The Adizes diagram above also demonstrates where lies the greatest inter-type conflict Types on the diagonal are the most different from each other and experience the most conflict. The Administrator is structured, slow, local process orientation has nothing in common with the Entrepreneur is unstructured, fast, global results orientation. Similar conflict exists between the Integrator and Producer.

Although many researches with cognitive approach has been done by using Myers and Briggs index about differences between people and managers, a scientific research on the causes of conflict between these four leadership style has not been done. A third zone of application of concern structure thinking in the Adizes Methodology arises in the context of its theory of organizational lifecycle dynamics. Like other lifecycle models, the Adizes organizational lifecycle describes several phases in the life of any project, from inception and growth through to maturation and decline. Each phase has its unique PAEI needs, and specific consequences for PAEI mismatches. The lifecycle is described in ten phases (capital letters indicate predominant style): Courtship [paEi], Infancy [Paei], Go-Go [PaEi], Adolescence [pAEi], Prime [PAEI], Stable [PA-I], Aristocracy [-A-I], Early Bureaucracy [-A--], Late Bureaucracy [-A--] and Death [----]. (capital letters in Figure 2, shows the dominant styles).

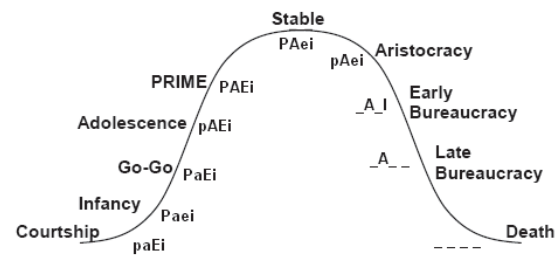

Figure 2. The organization life cycle (Adizes: 1987).

Choice theory was founded by Glasser in 1998, and the emphasis is on five basic human needs and Glasser (1998) believes that the motivation of all human beings originates from it. The needs are internal, universal, dynamic and compatible with each other. In the choice theory, it is believed that we're excited to build the "qualitative world" to satisfy our special needs. Qualitative world includes favorite people, ideas and desires. Do, is all that behavior that we do and it is usually purposeful. Qualitative world is made of peoples' understandings, situations and things that are positive. Our needs usually evoke as images, and these images show the life with need satisfaction that we would like to experience this life like (Sohn, 2004). But the specific actions that each person will select to satisfy the basic needs are unique (Loyd, 2005). People can create better opportunities, selecting effective ways to achieve Fun, Power, Freedom, Love and belonging, (Donato, 2004).

Glasser description of the behavior is more humanistic rather than behavioral and uses five basic needs to describe how we behave (Malone, 2002). Glasser's choice theory divided basic human needs into five parameters of Power, Survival, Love and belonging, Freedom and Fun (Glasser, 1998).

The need for survival: The caution in work, risk avoidance and awareness of that, the importance of financial issues, the importance of the sense of safety and security, the sexual needs.

The sense of belonging: love and affection, showing feelings and emotions to others, seeking intimacy, time and energy to the family communication, creating and maintaining friendships, membership in the group.

Power and Self-actualization: reaching the target, achievement, sense of control over the circumstances, having skills, having self-confidence, sense of honor, influence on others, a sense of competition, following a pattern and being followed.

Freedom: Not being limited and not force, feel the freedom of action and decision-making, travel, independence of judgment and action, following up, having plenty of choices, autonomy, creativity and expression without fear. and joy.

Fun: laughing, learning, variety seeking, addressing the favorite entertainment, having fun, playing, sense of humor

These five factors comprise the personality profile and outline the causes of the conflict between the individuals using this personality profile. This study is going to answer the question of whether the listed conflict matrix in Adizes pattern is related to the intensity of the basic needs of managers and also which one of the five basic requirements plays the most important role in the conflict. 


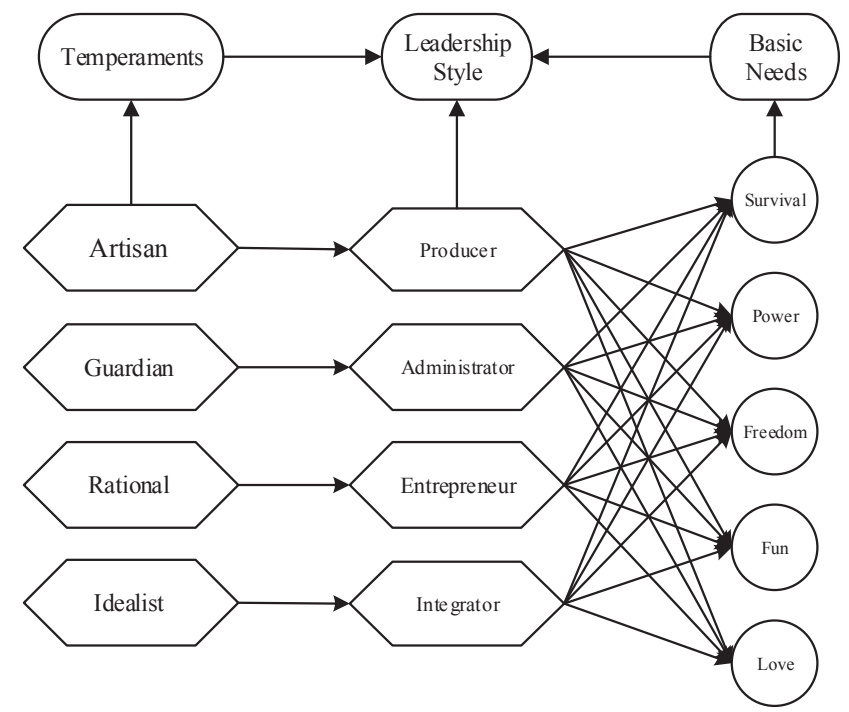

Figure 3. Theoretical Research frame Methods

The present research is a correlation study between the severity of needs for survival, freedom, Recreation, power and belonging to the four Adizes leadership styles (executive, administrative, entrepreneurial and integrative). The population of the study consisted of all senior managers (managers with over 10 years of experience and higher levels of operational supervision) the private manufacturing industry was in the city of Mashhad. The sample used in this study consisted of 36 senior directors of Toklan toos industrial and manufacturing group in the city of Mashhad.

\section{Research Instruments}

MBTI questionnaire: This questionnaire specifies the type of manager personality and predicts their management style using PAEI model. Gardner and Martinko (1996), reported reliability and validity of the questionnaire satisfactory. Caparo $\&$ Caparo (2002), calculated alpha coefficient of the questionnaire between 0.74 to 0.84 . The MBTI reliability coefficient was also reported between 0.83 to 0.94 in a period of four weeks by retest method.

Questionnaire of five Glasser's basic needs: The questionnaire rank measures the severity of managers needs in five degrees (from very low $=1$ to very high $=5$ ). . The above questionnaire is called Sahebi compatibility scale (2010), and consists of 25 questions that rates five internal needs. Cronbach's alpha coefficient of the Questionnaire of Glasser's basic requirements is reported between 0.73 and 0.78 . Reliability of research tools is also obtained between 0.45 and 0.73 by test-retest method.

\section{Data analysis}

Obtained data were entered into SPSS software and the Pearson correlation coefficient was used to determine the relationship between basic needs to identify the needs that are in conflict with each other, then the multivariate regression was used to examine the relationship between the needs associated with leadership styles.

To test the hypothesis of the research based on a conflict between leadership styles because of the difference of the basic requirements, the Pearson correlation coefficient and t-test were correlated in groups. First, to examine the relationship between our five basic needs, the Pearson correlation coefficient was used and the summary results are presented in Table 2. 
Table 2. Pearson correlation coefficients between basic requirements and administrative $(A)$ and entrepreneur $(E)$ leadership styles

\begin{tabular}{lcccccc}
\hline Needs & Leadership Style & Belonging & Power & Survival & Freedom & Fun \\
\hline Leadership Style & - & 0.135 & .042 & $-0.787^{7^{*}}$ & $0.743^{*+}$ & 0.173 \\
\hline Belonging & - & -0.361 & $-0.516^{*+}$ & -0.203 & 0.356 \\
\hline Power & & - & 0.099 & 0.028 & $-0.620^{*+*}$ \\
\hline Survival & & & - & $-0.533^{\text {** }}$ & $-0.483^{\text {** }}$ \\
\hline Freedom & & & & - & 0.089 \\
\hline Fun & & & & & - \\
\hline
\end{tabular}

According to Table 2, the management style is most correlated with the needs of survival and freedom. There is a significant relationship between Belonging and Survival, Power and Fun, Survival and Freedom and Survival and Fun ( $p$ $<0.01$ ). While a strong correlation was not found among other needs.

On the other hand, a strong and positive correlation was not found between any of the needs. In order to assess the impact of leadership styles (Administrator and Entrepreneur) on the needs of Power, Belonging, Fun, Survival, and Freedom, five regression models were fitted using least square error. That leadership style variable as the virtual independent variable is presented in all models and is based on dependent variable model. The summary results are presented in Table 3. As you can see, the p-value corresponding to the F statistics only in models of the impact of leadership style on Survival and Freedom is less than significant level of the test (0.05). So, Administrator and Entrepreneur leadership style has a significant impact to the Survival and Freedom needs.

Table 3. The results of regression methods to examine the impact of leadership styles on the basic needs of managers

\begin{tabular}{lccccccc}
\hline Model & $\begin{array}{c}\text { Parameter } \\
\text { Estimation }\end{array}$ & $\begin{array}{c}\text { Std. } \\
\text { Deviation }\end{array}$ & $\begin{array}{c}\text { Partial correlation } \\
\text { coefficient }\end{array}$ & $\begin{array}{c}\text { Determining factor } \\
\text { model }\end{array}$ & $\begin{array}{c}\text { Durbin-Watson } \\
\text { Statistics }\end{array}$ & $\begin{array}{c}\mathrm{F} \\
\text { Statistics }\end{array}$ & $\begin{array}{c}\text { P- } \\
\text { Value }\end{array}$ \\
\hline $\begin{array}{l}\text { The impact of leadership } \\
\text { style on the Power }\end{array}$ & -0.049 & 0.225 & -0.04 & 0.00 & 2.48 & 0.048 & 0.829 \\
\hline $\begin{array}{l}\text { The impact of leadership } \\
\text { style on the Belonging }\end{array}$ & -0.171 & 0.241 & -0.13 & 0.02 & 2.42 & 0.499 & 0.486 \\
\hline $\begin{array}{l}\text { The impact of leadership } \\
\text { style on the Fun }\end{array}$ & -0.229 & 0.251 & -0.17 & 0.03 & -2.19 & 0.836 & 0.369 \\
\hline $\begin{array}{l}\text { The impact of leadership } \\
\text { style on the Survival }\end{array}$ & 1.487 & 0.224 & 0.79 & 0.62 & 2.52 & 43.982 & 0.000 \\
$\begin{array}{l}\text { The impact of leadership } \\
\text { style on the Freedom }\end{array}$ & -1.100 & 0.191 & -0.74 & 0.55 & 2.37 & 33.210 & 0.000 \\
\hline
\end{tabular}

According to the values reported in Table 3, it can be seen that the coefficient of determination, as a model to investigate the effect of leadership style has the highest coefficient of determination for Survival. This means that this model is stronger than the other models. After that, the coefficient of determination of the Freedom model to examine the effect on leadership style is in second place. Also, the reported values of partial correlation coefficients describe the influence of the severity and type of leadership style on the studied requirements. For example, the impact of leadership style on negative Freedom and Survival (because the partial correlation coefficient is negative) is direct.

\section{Conclusion}

The purpose of this study is to examine the relationship between leadership styles and the basic requirements of managers. According to Glasser, humans have five basic needs of Survival, Love and belonging, Power, Freedom and Fun four of which are mental needs. The only need that is biological and physical is Survival (Glasser, 1998). In this study, a positive correlation between the five basic needs was found, which showed that people who are more severe in one of the needs, will differ in other needs.

The findings of this study match with the idea that there is a conflict between two Adizes Administrator and Entrepreneur leadership styles and show that the group is considerably different in biological and psychological needs. In fact, people with A style, which has a personality of Sensing- Judging, due to the extremely high need for Survival, tend to have conservative management style, which is in direct confrontation with the INtuition-Thinking, that are in high need of 


\section{Freedom.}

The behavioral study of the research, we found that the organization remains in maturity. On the other hand, one of the other findings was that the organization has a dominant style of pAEi ( $A$ and $E$ are dominant to $P$ and $I$ ). The above results are compatible with Adizes opinion that the dominant leadership style is in Adolescence, administrative and entrepreneur period (Adizes, 1987). Since Adolescence is a period in which styles conflict with each other, we can conclude that the evolution of this lifecycle to Prime lifecycle (PAEi) will be the most difficult challenge.

In this regard, Hornady and Abod (1971), Nikumaram and Heidarzadeh, (1385), suggest that successful entrepreneurial managers believe in themselves and do not attribute their success or failure to fate, luck or similar forces. According to them, failure and progress is in their influence and they are effective to result operations. Karami et al (1387), showed that good interpersonal relationship is the cause of the spirit of cooperation and collaboration of managers. Thus, with better cooperation and consultation instead of competing with each other, employees will be able to take advantage of the available opportunities and increase entrepreneurial behavior of the organization. In the Rhee and Rebecca survey (2007), it was found out that a high level of self-esteem, achievement, service orientation, teamwork, cooperation and the ability to maintain the highest standards of honesty and integrity in emotional competencies is seen in creative and entrepreneurs managers. Leonidas et al (2008), found in a study that in creativity and entrepreneurship of managers and their passivity, emotional intelligence plays an important role. Leonidas et al (2009), in another study mentioned the role of emotional intelligence in management behavior in organizations, and report a negative relationship between corporate responsibility and behavior management. Hallajan (1388) found that there are differences in the level of emotional intelligence competencies for men and women, and it means that men have higher score in self-regulation and self-motivation and women in empathy, Self-awareness and social skills, and the amount of emotional intelligence with the change of in management positions has increased dramatically. Langhorn (2004) mentioned the role of emotional intelligence to improve performance and the relationship between emotional competencies of managers with the efficiency and effectiveness of the organization under the direct control of them. Virginia et al (2011) reported the effectiveness of emotional intelligence on self-awareness and performance management, especially self-acceptance and acceptance of others and performance. The results also showed that there is a strong relationship between emotional intelligence and leadership performance in managers who underestimated their ability. But there is a negative relationship between the emotional intelligence and leadership performance for managers who exaggerated in their leadership abilities. Hao Jiao et al (2010), reported in a survey that entrepreneurial orientation of managers (innovation, risk, hyperactivity) and different levels of organizational learning and dynamic capabilities are related. There is a significant positive relationship between the ability of individual and entrepreneurial attitudes of managers. The merits of individual causes the increasing entrepreneurial tendencies of managers. In other words, personal skill holders (self-awareness, self-management, self-motivation) are inventive, creative, innovative, pioneering and risk-taking people and organization should equip their human resources with creating necessary conditions, individual skills and the ability to mobilize, so that using this capability, other community resources and organizations can manage and conduct value and achieve growth and development. Results of prior study of Hadizadeh et al (1388), Shepard (2004), Langhorn (2004), and Poilas et al (2010), showed that emotion management causes to increase creativity and entrepreneurship of managers. Therefore, people who tend to keep destructive emotions are self-control, accept of responsibility and new ideas and accept approaches openly, they are creative, pioneering and entrepreneurial and tend to entrepreneurship. Thus, according to the results of the Friedman ranking (control of emotion, regulation and management), management of emotions and feelings can be used as a key variable for determining the amount of entrepreneur of managers. Hadizadeh et al (1388), showed that there is no significant relationship between social skills and entrepreneurial attitude of managers. Therefore, people communication and linking (communication tool strengthening), leadership and participation cannot cause a good innovation, leadership and risk.

This study had some limitations. The sample for this study was piece makers of automobiles and related industries and the impact of technology on structure, other industries and government organizations have not been investigated. Another limitation was that the sample of all subjects related to the maturity of an organization and Executive $(P)$ and the integration (I) Styles was not examined due to lack of experimental samples. Therefore, we must be careful in generalizing it to a variety of organizations. Certainly, future studies on organizations that are located in other periods of lifecycle, will open more valves of leadership styles and personality typology of them on intensity basic needs. It is recommended that:

Considering the fact that most of the companies surveyed in the study of leadership styles are A Type, and are at the end of their maturity and are complicated premature aging, so to get out of this problem, it is suggested that managers with the $E$ type leadership style are used more in key -management positions.

- To avoid fatigue and pale challenges of the founder, it is recommended to strengthen the spirit of $E$ in 
organizational leadership.

- Due to the differences in the basic requirements of team work, it is suggested to managers to consider differences normal, and walk in the direction of mutual understanding.

- Due to the fact that from Adizes point of view, effective team is a team in which four leadership styles involved in, but it is important that the results of this study examined that management style at senior levels of $\mathrm{P}$ and I are very few.

\section{References}

Adizes, I. (1981). How to Solve the Mismanagement Crisis. Santa Monica, CA: Adizes Institute.

Adizes, I. (1987). Corporate lifecycles. Santa Monica, CA: Adizes Institute.

Adizes, l.: Adizes Management Resources, http://www.adizes.com

Aldrich, H. E. (1979). Organizations and Environments. Englewood Cliffs, New Jersey: Prentice-Hall.

Allport, G.W. (1937). Personality: A Psychological Interpretation. New York: Holt.

Armstrong, S.J., Cools, E. and Sadler-Smith, E. (2012). Role of Cognitive Styles in Business and Management: Reviewing 40 Years of Research. International Journal of Management Reviews, 14, pp.238-262

Benfari, R. (1991). Understanding Your Management Style. NY: Lexington Books.

Chandler, A. D. (1962). Strategy and structure: Chapters in the history of American industrial enterprise.Cambridge, Massachusetts: The MIT Press.

Capraro, R. M., \& Capraro, M. M. (2002). Myers-briggs type indicator score reliability across: Studies a meta-analytic reliability generalization study. Educational and Psychological Measurement, 62, 590-602. Business and Management: Reviewing 40 Years of Research. International Journal of Management Reviews, 14, pp.238-262

across: Studies a meta-analytic reliability generalization study. Educational and Psychological Measurement, 62, 590-602.

Coe, CK. (1992) The MBTI: Potential uses and misuses in personnel administration. Public Personnel Management, 21(4), pp:511-522.

Galton, F. (1883). Inquiries into Human Faculty and Its Development. London: Macmillan.

Gardner, W.I. and Martinko, M.J. (1996). Using the Myers- Briggs Type Indicator to study managers: a literature review and research agenda. Journal of Management, 22, pp. 46-83.

Glasser, W. (1998). Choice Theory: A New Psychology of Personal Freedom. New York, NY: HarperCollins.

Gul, F.A. (1986). A note on the relationship between age, experience, cognitive styles and accountants' decision confidence. Accounting and Business Research, Winter, pp. 85-88.

Hadizadeh, A., Raminmehr, H., and Hosseini, S. (2009). The relationship between emotional intelligence and entrepreneurial orientation. (2009). Journal of Entrepreneurship Development, 2(4), pp: 139-162.

Hicks, E., Bagg, R., Doyle, W. and Young, J.D. (2007). Public accountants' field dependence: Canadian evidence. Perceptual and Motor Skills, 105, pp. 1127-1135.

Hough, J.R. and Ogilvie, D.D. (2005). An empirical test of cognitive style and strategic decision outcomes. Journal of Management Studies, 42, pp. 417-448.

Isachsen, O. and Berens, L. V. (1989). Working Together: A Personality Centered Approach to Management (2nd Ed). Coronado, Calif.: Neworld Management Press.

Karami, A., Bahrami, F., and Maghsoudi, J. (2009). Emotional intelligence, entrepreneurship missing link, Rouyesh Magazine, 12, pp: 39-52.

Jung, C.G. (1923). Psychological Types. London: Routledge \& Kegan Paul.

Kirsey D. and Bates M. (1984). Please understand me: character \& temperament types. Toronto, CA: Prometheus Nemesis

Margerison, C. J. and Lewis, R. (1981). Mapping managerial styles. International Journal of Manpower, 2(1), pp:2-24.

Messick, S. (1976). Personality consistencies in cognition and creativity. In Messick, S. (ed.), Individuality in Learning. San Francisco, CA: Jossey Bass, pp. 4-22.

Myers, I. B., McCaulley, m. H. (1985). M. Manual: A guide to the development and use of the Myers-Briggs Type Indicator. Palo Alta, CA: Consulting psychologists Press.

Nikumaram, H. and Heidarzadeh, K. (2006). Evaluation the Role of Entrepreneurial Proclivity Organization Structure and Market Orientation on Business Performance. Journal of Marketing Management, Tehran Faculity of Science and Research, Islamic Azad University, 1(1), pp: 5-50.

Nordvic, H. and Brovold, H. (1998). Personality traits in leadership tasks. Scandinavian Journal of Psychology, 39, pp: 61-64.

Parkinson, J. and Taggart, S. (2007). Jobs and careers: earning and outgoing. Financial Management, July/August, pp: 55-57.

Peters, T. J., \& Waterman, R. H. (1982). In search of excellence: Lessons from America's best-run companies. NY: Harper \& Row.

Recker, L. (1991). PAEl and Myers-Briggs Typologies. Santa Monica, CA: Adizes Institute.

Riding, R.J. and Rayner, S.G. (1998). Cognitive Styles and Learning Strategies. London: David Fulto Publishers.

Rodriguez Montequin, V.,Mesa Fernandez J. M., Balsera J. V.,_, García Nieto, A. (2013). Using MBTI for the success assessment of engineering teams in project-based learning. Int J Technol Des Educ, 23, pp:1127-1146

Reynierse, J.H. 1(1995). A comparative analysis of Japanese and American managerial types through organizational levels in business and industry. Journal of Psychological Type, 33, pp:12-19. 
Reynierse, J.H., Harker, J.B. 1995. The psychological types of line and staff management: Implications for the J-P preference. Journal of Psychological Type, 34, pp:8-16.

Schloemer, P.G. and Schloemer, M.S. (1997). The personality types and preferences of CPA. firm professionals: an analysis of changes in the profession. Accounting Horizons, 11, pp. 24-39.

Szilagyi, A. D., and Schweiger, D.M. (1984). Matching Managers to Strategies: A Review and Suggested Framework. The Academy of Management Review, 9(4), pp:626-637.

Tan, V., and Tiong, T.N. (2001). Personality type and the Singapore manager: Research findings based on the MBTI. Singapore Management Review, 23 (1), pp:15-31.

Tichy, N. M. (1982). Managing change strategically: The technical, political, and cultural keys. Organizational Dynamics, Autumn, pp: 5980

Witkin, H.A., Moore, C.A., Goodenough, D.R. and Cox, P.W. (1977). Field dependent and field independent cognitive styles and their educational implications. Review of Educational Research, 47, pp. 1-64.

Woodruffe, C. 2006. How managers and non-managers differ in their MBTI personality type. Retrieved October 15, 2009, from www.peoplemanagement.com 